\title{
Discomfort in the use of intimate apparel by elderly women: information for product development
}

\author{
Crislaine Gruber, Alexandre Amorim dos Reis, Giovana Zarpellon Mazo \\ Universidade do Estado de Santa Catarina \\ e-mails: crislaine.gruber@ifsc.edu.br; alexandre.a.reis@gmail.com; giovana.mazo@udesc.br
}

\begin{abstract}
This paper aims at identify the problems and the factors that cause discomfort in bra use by elderly women. Interviews were conducted with 45 women, aged between 60 and 83, from the Program of University Extension Group of Studies of the Third Age at the State University of Santa Catarina. Regarding the major problems perceived in the use of the bra, the participants highlighted the product sizes grid and certain parts of its structure, mainly the back band, the cups, and the straps. Other problems highlighted were: the rapid degradation of the product, high prices, and sweating. Regarding factors that cause discomfort in the use of the bra, the most cited by the participants was the thermophysiological (48.9\%), followed by fitting (37.8\%), and sensorial (24.4\%). In face of the problems presented by the participants, it is concluded that ergonomics plays a key role in the development of products compatible with the needs, abilities, and limitations of the elderly, which represent a significant portion of the Brazilian population. Results of this study should be considered when designing intimate apparel for the elderly.
\end{abstract}

Keywords: ergonomics, elderly women, bra, discomfort assessment, intimate apparel design.

\section{Introduction}

Population aging is a reality in Brazil. It is estimated that between 2011 and 2050, the population over 60 years old will increase from $10.25 \%$ to $29.75 \%$ its proportion in the total population (INSTITUTO..., 2008). By the year 2050 the number of sexagenarian women in Brazil will reach over a million and a half, a significant increase compared to 868,307 women aged 60 that compose the Brazilian population pyramid of 2014 (INSTITUTO..., 2014).

Although population aging is found worldwide, the elderly suffer physical and psychological constraints due to lack of attention and the inefficient project of products that do not consider their limitations and characteristics (SPINOSA, 2007). Products for daily use, such as clothing, can generate uncomfortable interactions with the elderly. Clothing, for maintaining direct contact or very close to the skin, should be designed according to the physical, physiological and morphological characteristics of the user. However, there are few studies in the area of clothing design for the elderly (MENEGUCCI; SANTOS FILHO, 2010).

The use of underwear can cause, besides the discomfort, health problems for the user. Inadequate bra can cause, among other problems, pain in the shoulders, neck and back (KAGIYAMA, 2011). Older women may face greater challenges to find a bra with a good fit due to anatomical and physiological changes associated with aging (RISIUS, 2012).

Faced with the problems encountered by the elderly in daily interaction with unsuitable products, ergonomics acquires an important role. Ergonomics is a discipline that aims at optimizing human well-being and overall system performance, making products, organizations, tasks, environments and systems compatible with the needs, abilities and limitations of people (INTERNATIONAL..., 2016).

This paper presents part of a master's research in Design, developed at the State University of Santa Catarina, and aims at identify the problems and the factors that cause discomfort in bra use by elderly women. Results of this research can be used as a reference for intimate apparel design for elderly.

\section{Theoretical contextualization}

\subsection{Woman aging}

The woman's aging process involves a series of physical changes that affect their body measurements and their interaction with the clothes. These changes directly influence the perception of discomfort of the elderly women in relation to clothing. A significant example is the 
loss of elasticity and efficient thermoregulation of the skin (SPIRDUSO, 2005).

There is also a gradual decrease in body height, mainly due to bone loss. Normally, weight and body fat increase from 40 to 60 years, and decrease after 70 years of age. There is loss in area of the skeletal muscles and muscle strength (MATSUDO; MATSUDO; BARROS NETO, 2000). Concerning flexibility, the loss occurs much earlier, mainly in the back (SPIRDUSO, 2005).

The physical changes related to aging do not prevent that most seniors perform the basic activities of self-care: only $4 \%$ of the elderly over 65 years old present severe disability and $20 \%$ present a mild degree of disability (NERI, 2001). The dressing is one of the activities that the elderly continue to play over time.

\subsection{Discomfort in the use of the bra}

Discomfort can be defined as an unpleasant state of the human body in reaction to its physical environment (VINK; HALLBECK, 2012). When it comes to clothing, different researchers deal with the issue and define, often with distinct terms, the aspects that influence the feeling of discomfort, converging to: mechanical/movement, thermal, aesthetic, sensorial and psychological (GRUBER; REIS, 2013).

Regarding the intimate apparel, Yu (2011) defines as aspects of comfort: sensorial, thermal, motion, aesthetical and hygienic. This paper presents the evaluation of three of these aspects (sensorial, thermal and motion - here called fitting). The sensorial aspect corresponds to the tactile sensation (e.g. smooth or rough, cold or warm, soft or hard, tight or loose), to avoiding skin irritation, and allowing comfortable pressure. Thermal aspect is related to hygroscopicity of underwear fabric, heat transmission, and moisture management fibers for intimate apparel. The motion aspect concerns the challenges of fitting, including fitting for special needs, e.g. elderly users.

Motion aspect is related to the sizes of the products. In Brazil, there is no standardization in the tables of body's measures and no variety of bra sizes that meets the different women's biotypes. Few bra manufacturers differentiate the band size and the size of the cups (GRUBER, 2014). Studies suggest that $70-100 \%$ of women wear the wrong size bra, and for women with large breasts, the difficulty of finding a bra with good fit is even higher (MCGHEE; STEELE, 2006). The lack of standard tables of measures and the body variations of the users can cause discomfort to them (NEVES; BRIGATTO; PASCHOARELLI, 2015).

Coupled with the lack of standard measures that meet the different biotypes of Brazilian women, among them the elderly, is the complexity of developing the bra patterns. Their construction requires a lot of knowledge about the measures and movements of the human body, in addition to the behavior of textiles (YU; WANG; SHIN, 2006).

\section{Methods}

This research was approved by the Ethics Committee for Research Involving Human Beings of the State University of Santa Catarina. The study included 45 women aged 60 or older, residents in Florianópolis, Santa Catarina, who wear bra every day, in size equal to or greater than 46 or G, and who did not undergo surgery on their breasts. Participants were selected in non-probabilistic way and consented to answer the interview questions after signing the Term of Free and Informed Consent. From the interview form, were extracted the data from two questions for the presentation, analysis and discussion in this paper. The completed form and all the research presentation are available in Gruber (2014).

It was asked to the participants what the biggest problem they perceive in bra and what factors cause discomfort when using bra: thermophysiological, fitting, or sensorial. The answers were analyzed qualitatively and quantitatively, using descriptive statistics.

\section{Results and discussion}

The average age of the study participants is 69.6 years, with standard deviation of 5.56. Most of them are married (51\%) and $35 \%$ are widows. The most widely used bra size is number $46(51.1 \%)$, followed by the number $48(40 \%)$, $50(6.7 \%)$, and $52(2.2 \%)$.

On being asked about the biggest perceived problem while using the bra, 13 participants ( $28.8 \%$ of the sample) said they had no problems. For one of them the problem is in her body, "there's no way after a certain age". This feeling of dissatisfaction with the aging body can cause a woman to have the perception that the discomfort problem is due to her body, not to the product in use. Ergonomics, on the other hand, defends that the products must be developed to suit the user's needs, abilities and limitations. The changes in the female body caused by aging, as shown by Matsudo, Matsudo and Barros Neto (2000) and Spirduso (2005), influence in the relationship the elder user has with the products.

Most of the study participants relate problems to certain parts of the bra's structure, being the most cited the back band, the cups and the straps (Figure 1). Two participants cited fabrics as the most perceived problem. The textile materials influence the sensorial aspect of the discomfort in clothing, being an important aspect to be considered in the product development (YU; WANG; SHIN, 2006).

Ten participants $(22.2 \%)$ stood out as the biggest perceived problem in the bra use the sizes of the product, as shown in their statements (Table 1). In Neves, Brigatto and Paschoarelli's study (2015), that interviewed 107 women with an average age of 22.74 years, $51.40 \%$ of participants have difficulty finding bra that fit to their breast and back 
Table 1. Statements of the participants related to the problems in bra sizes.

\begin{tabular}{|c|l|}
\hline Participant & \multicolumn{1}{c|}{ Answer } \\
\hline P2 & $\begin{array}{l}\text { In Brazil, bras are not well adjusted. In the United States, the cup is more adjustable. The cup is classified by numbers and } \\
\text { is appropriated to the size of the breasts. }\end{array}$ \\
\hline P5 & I do not find bra cup size that is large enough and with smaller lower back, because I have small back. \\
\hline P6 & Adjusting the straps and hooks. \\
\hline P7 & On the back, it is necessary to have more size settings. \\
\hline P11 & It does not have the appropriate size. \\
\hline P20 & Must have more adjustment options in the back size. The back band should be smaller. \\
\hline P21 & Finding a bra for bigger breasts. Sometimes size 50 does not fit. Variability of size table between the brands is a problem. \\
\hline P28 & The cups are too small. \\
\hline P36 & When the shape of the cups is small. \\
\hline P43 & In the breasts are small. \\
\hline
\end{tabular}

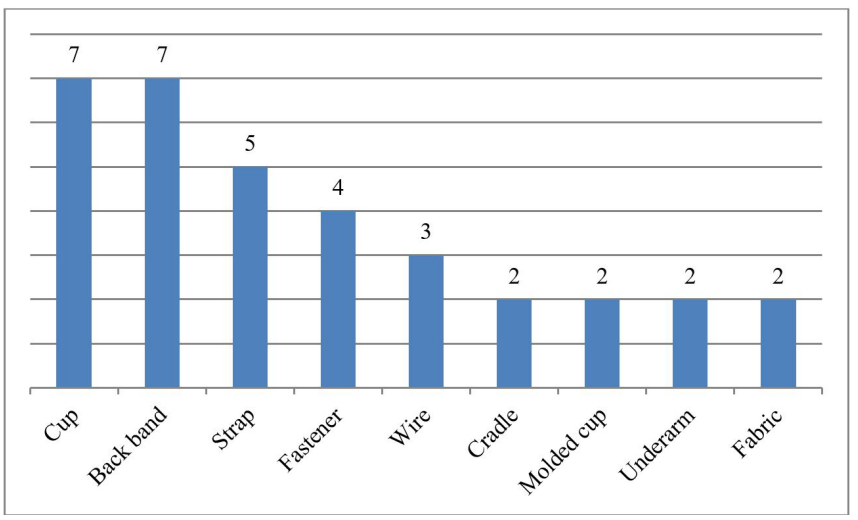

Figure 1. Bra elements that cause the greatest problems for elderly women while using the product. Source: the authors.

sizes. Therefore, this is a problem perceived by elderly and young users.

Other problems highlighted were: rapid degradation of the product (three participants), high prices (two participants) and sweating (two participants). The price and the durability of bras are also aspects considered by young users. In Kagiyama (2011), a research conducted with 22 women aged 17 to 29 years old, $84.9 \%$ of the participants said that price is the most important aspect when buying bras. In Neves, Brigatto and Paschoarelli's (2015) research, $87.8 \%$ of the participants consider the durability of underwear an important product attribute.

When electing the most perceived problems in using bras, some participants suggested the following recommendations for bra design: putting the fastener in front, because they feel pain turning the bra; making the back band more wider; making seamless cups that be invisible under the shirt; doing more size adjustment options on the back band; increasing the support of the breasts; making simpler bras; making bras without lace; making the underarm in a way that the bra covers the entire side of the breast; using larger fasteners; making larger cradles.
Regarding factors that cause discomfort in the use of the bra, the most cited by the participants was the thermophysiological (48.9\%), followed by fitting (37.8\%) and sensorial (24.4\%); $6.7 \%$ did not know or did not answer. Women aged 80 years or more did not mention the fitting and sensorial aspects. Among the participants of 70 to 79 years of age, the most cited aspect was the thermophysiological (56.3\%); only $12.5 \%$ of them pointed to the sensorial aspect.

Participants who showed less variation between the mentioned aspects were the ones aged between 60 and 69 years old: thermophysiological (40\%), fitting (52\%) and sensorial (36\%). In Kagiyama (2011), only 26.3\% said they felt fuggy when using the bra, while for $48 \%$ the fitting is not good. Regarding the sensorial aspect, $40.2 \%$ of the Kagiyama's sample said it is important the bra to be soft to them purchase it. Therefore, it is clear that while for the young ones the fitting and sensorial aspects seem to have greater importance, for the elderly the thermophysiological factor is the one that cause most discomfort.

\section{Conclusions}

This study aimed at identifying problems and factors that cause discomfort in bra use by elderly women. The perceived problems in bra use by elderly women are the product sizes and certain parts of its structure, as the back band, the cups and the straps. Rapid degradation of the product, high prices and sweating were cited by participants too. As for the factors that cause discomfort in bra use by the elderly, it is highlighted the thermophysiological, followed by fitting and sensorial factors.

Results of this study are limited due to the nonprobabilistic research method. However they can be applied in intimate apparel design for elderly. Perceptions of the participants give some important information to the product development process. As stated by Yu, Wang and Shin (2006), the construction of bras requires that designers have knowledge in different areas, such as human measurements, movements of the human body, behavior of the fabrics; 
furthermore, it is necessary that intimate apparel design to be supported by technologies that allow testing products in order to make them compatible with users characteristics. Virtual ergonomic analysis are an example of approach that should be incorporated by apparel design, as they represent low cost and good performance alternative for improving the design delivered to the consumer market providing more comprehensively the consumer needs (RAMOS; REIS, 2014).

Ergonomics plays a key role in the development of products compatible to the needs, abilities and limitations of the elderly, which represent a significant portion of the Brazilian population. It is necessary to educate elderly women that products need to be developed to suit their needs, abilities and limitations, as established by ergonomics. The characteristics of different users need to be considered in the product development.

\section{Acknowledgements}

The Support Fund Program for Maintenance and Development of Higher Education (FUMDES) supported this work.

\section{References}

GRUBER, C. O desconforto no uso do vestuário íntimo: avaliação da percepção pelo público idoso feminino. 137 p. Dissertação (Mestrado em Design) - Centro de Artes, Universidade do Estado de Santa Catarina, Florianópolis, 2014.

GRUBER, C.; REIS, A. A. Ferramentas para avaliação do conforto no uso do sutiã. In: COLÓQUIO DE MODA, 9., 2013, Fortaleza. Anais... Fortaleza: Abepem, 2013. p. 1-12. Available from: <http://www.coloquiomoda.com.br/ anais/anais/9-Coloquio-de-Moda_2013/COMUNICACAOORAL/EIXO-1-DESIGN_COMUNICACAO-ORAL/

Ferramentas-para-avaliacao-do-conforto-no-uso-do-sutia. pdf $>$. Access in: 1 Dec 2015.

INSTITUTOBRASILEIRODEGEOGRAFIAEESTATÍSTICA. Projeção da população: pirâmide etária absoluta. [S.l.]: IBGE, 2014. Available from: < http://www.ibge.gov.br/home/ estatistica/populacao/projecao_da_populacao/2008/piramide/ piramide.shtm>. Access in: 30 Nov 2015.

INSTITUTOBRASILEIRODEGEOGRAFIAEESTATÍSTICA. Projeções 1980-2050: revisão 2008. [S.1.]: IBGE, 2008. Available from: $<$ http://servicodados.ibge.gov.br/Download/ Download.ashx? $\mathrm{u}=\mathrm{ftp}$. ibge.gov.br/Projecao_da_Populacao/ Revisao_2008_Projecoes_1980_2050/Revisao_2008_ Projecoes_1980_2050/Projecoes_1980_2050_revisao_2008. zip>. Access in: 30 Nov 2015.

INTERNATIONAL ERGONOMICS ASSOCIATION. Definition and domains of ergonomics. Available from: $<$ http://www.iea.cc/whats/>. Access in: 10 June 2016.
KAGIYAMA, W. Design de vestuário íntimo: o sutiã sob abordagem de conforto. 2011. 186 f. Dissertação (Mestrado em Design) - Faculdade de Arquitetura, Universidade Federal do Rio Grande do Sul, Porto Alegre, 2011. Available from: <http://www.lume.ufrgs.br/bitstream/ handle $/ 10183 / 32633 / 000787569$.pdf? sequence $=1>$. Access in: 30 Nov 2015.

MATSUDO, S. M.; MATSUDO, V. K. R.; BARROS NETO, T. L. Impacto do envelhecimento nas variáveis antropométricas, neuromotoras e metabólicas da aptidão física. Revista Brasileira de Ciência e Movimento, Brasília, v. 8, n. 4, p. 21-32, 2000. Available from: <http:// www.lifegroup.com.br/fe10.pdf $>$. Access in: 30 Nov 2015.

MCGHEE, D. E.; STEELE, J. R. How do respiratory state and measurement method affect bra size calculations? British Journal of Sports Medicine, [S.1.], v. 40, n. 12, p. 970974, 2006. http://dx.doi.org/10.1136/bjsm.2005.025171. Available from: <http://www.ncbi.nlm.nih.gov/pmc/ articles/PMC2577461/pdf/970.pdf > . Access in: 1 Dec 2015.

MENEGUCCI, F.; SANTOS FILHO, A. G. Proteção e conforto: a relação entre os tecidos e o design ergonômico do vestuário para idosos. In: CONGRESSO BRASILEIRO DE PESQUISA E DESENVOLVIMENTO EM DESIGN, 9., 2010, São Paulo. Anais... São Paulo: Universidade Anhembi Morumbi, 2010. p. 1-11. Available from: <http:// blogs.anhembi.br/congressodesign/anais/artigos/69803. pdf $>$. Access in: 30 Nov 2015.

NERI, A. L. Envelhecimento e qualidade de vida na mulher. In: CONGRESSO PAULISTA DE GERIATRIA E GERONTOlogia, 2., 2001, São Paulo. Anais... São Paulo: SBGG, 2001. p. 1-18. Available from: $<$ http://portaldoenvelhecimento.com/old/artigos/ maio2007/2congresso.pdf > . Access in: 30 Nov 2015.

NEVES, E. P.; BRIGATTO, A. C.; PASCHOARELLI, L. C. Moda íntima: uma abordagem acerca dos aspectos de usabilidade. Human Factors in Design, Florianópolis, v. 4, n. 8, p. 58-75, 2015. Available from: $<$ http://revistas. udesc.br/index.php/hfd/article/view/6656/4738>. Access in: 1 Dec 2015.

RAMOS, M.; REIS, A. A. Virtual analysis as a way of inclusion of the elderly in ergonomic testing. Product: Management \& Development, [S.1.], v. 12, n. 2, p. 84-88, 2014. Available from: <http://pmd.hostcentral.com.br/revistas/vol_12/nr_2/ v12n2a03.pdf $>$. Access in: 10 June 2016.

RISIUS, D. J. An investigation of breast support for older women. 2012. $218 \mathrm{f}$. Thesis (Ph.D. Course of Breast Health) - Department of Sports and Exercise Sciences, University Of Portsmouth, Portsmouth, 2013. Available from: $<$ http:// eprints.port.ac.uk/11850/1/Deborah_J._Risius_(2013) _Ph.D___An_investigation_of_breast_support_for_ older_women.pdf>. Access in: 30 Nov 2015.

SPINOSA, R. M. O. Interface antropométrica digital: parâmetros antropométricos de populações extremas. 2007. 89 f. Dissertação (Mestrado em Desenho Industrial) - Faculdade 
de Arquitetura, Artes e Comunicação, Universidade Estadual Paulista, Bauru, 2007. Available from: <http://www4.faac. unesp.br/posgraduacao/design/dissertacoes/pdf/Rodrigo_ spinosa.pdf $>$. Access in: 30 Nov 2015.

SPIRDUSO, W. W. Dimensões físicas do envelhecimento. Barueri: Manole, 2005.

VINK, P.; HALLBECK, S. Editorial: comfort and discomfort studies demonstrate the need for a new model. Applied Ergonomics, [S.1.], v. 43, n. 2, p. 271-276, 2012. Available from: <http://api.elsevier.com/content/article/PII:S0003687 011000743?httpAccept=text/xml>. Access in: 30 Nov 2015.

YU, W. Achieving comfort in intimate apparel. In: GUOWEN, S. (Ed.). Improving comfort in clothing. Cambridge: Woodhead Publishing, 2011.

YU, W.; WANG, J.-P.; SHIN, K. Bra pattern technology. In: YU, W. et al. (Eds.). Innovation and technology of women's intimate apparel. Cambridge: Woodhead Publishing, 2006. 